\title{
The industrial architecture of Mauro Lleó in the growth of the modern Valencia
}

\author{
Carmen Martínez Gregori \\ Escuela Técnica Superior de Arquitectura, Universitat Politécnica de València. Spain \\ E-mail: carmargr@cpa.upv.es
}

\begin{abstract}
After the urban stagnation that supposed the autarchic stage, began the true urban "boom" that would double the urbanized area of the city of Valencia. From the radio-concentric structural solution proposed by the PGOU of 1946, new urban and industrial development axes were established, the western one being Manises-Quart de Poblet-Aldaia, specialized in the metal industry. But the Plan was not feasible without a network of roads that would give the historic roads the right proportion to their new condition. This is the case of the Cami Reial de Castilla that in 1953 opened to traffic, becoming the new entrance of the road from Madrid to the city of Valencia and the connection with the airport of Manises. This created a great commercial and industrial axis along where large companies would be installed given their good communications with the state capital. This is the case of the Coca-Cola bottler (1958), the metal processing plant FLEX (1961) or the S.E.A.T. subsidiary (1965), all of which are the work of the same architect, Mauro Lleó Serret (1914-2001), who became pioneer in the construction of modern Valencia. It is important to know the architecture that has helped to configure part of our city, in this case the one that connects with its western metropolitan area, giving it a façade that will approach solutions already used by the great masters of architecture like Mies.
\end{abstract}

Keywords: radio-concentric structure, industrial axis, Coca-

Cola, FLEX, S.E.A.T.

\section{Introduction}

Once the urban stagnation of the autarchic stage between the years 1939 and 1957 was overcome, a great urban growth began that would double its urbanized area through a tentacular model oriented towards the tertiary economy.

In the 1940s, the Higher Order Commission of the Province was created, specifically in 1944, and had as its initial task the drafting of a provincial plan, which was not finally processed but would serve for the drafting of a General Plan of Urban Planning of the city that finally was approved the 18 of December of 1946.

This General Plan affected most of the municipalities in the region, which were thus placed at the service of the central city by means of a radiocentric model on which the new axes of urban growth were located: two of them residential, towards Burjassot- Godella and Torrent, and three industrial, to the north the textile-chemical, to the west the metal industry and ceramist of Manises-Quart of Poblet-Aldaia and to the south the logger. Thus, different sectors with a specific functionality were delimited, leaving between them the areas of industrial tolerance (the round and the Road of Transits), first and third ring widening from the old core and industrial preference zones to the east and northeast of the city.

But the Plan was not viable without an extension of the road network and for that reason new radial routes were opened and historical routes saturated and congested, such 
as Camí Reial de Castilla, which also proposed to divert (Gaja y Boira, 1994).

In 1953, the avenue of Castilla, completely paved, opened to traffic. It became the new entrance from Madrid to the city of Valencia as an extension of the streets of Pintor Benedito, San José de Calasanz and San Francisco de Borja. The project had a width of forty meters from the Transit Trail to the junction with the Lliria train and from there to the Torrent road sixty-five, although for a time the avenue was only ten meters wide with side areas to Ride or carriage, leaving the airfield of Manises only nine kilometers from the center. This created a great commercial and industrial axis along which would be installed large companies given their good communications with the capital of the state, Madrid.

The decade between 1960 and 1970 is the period in which the urban and demographic growth of the city spread quickly to other centers of L'Horta and one could say that it was when the Metropolitan Area of Valencia was effectively created. The city remained as a service center, coordinator of the whole area, and led to the decentralization of industrial activity in the peripheral nuclei that had to be delimited, attracting large numbers of immigrant population. Of these nuclei was the one of L'Horta Oest (Manises-Quart of PobletAldaia) that experienced greater growth due to its industrial activity, since it already had a substrate craft that facilitated the development of industrial estates.

\section{Methodology}

There are various ways of dealing with the analysis of historical architecture. This article intends to analyze three works of Mauro Lleó Serret architecture, in a period, 1953-1970, and in a concrete space, Valencia, to understand how modern architecture is able to configure city, creating its facades, organizing its spaces... The difficulty, however, lies in converting isolated facts into universal realities that can verify the starting hypotheses. The inductive method is used to demonstrate a series of propositions from a given number of cases.

These cases belong to the field of industrial architecture where the constructive innovations are introduced more quickly, and these will be the ones that give us generalizable answers based on the established hypotheses.

For the analysis of each work is essential to know all the existing documentation. Projects are then used in the public archives of the municipalities where they are located, in the personal archives of the architect and in the publications where they have been made known. This fact allows us to know the original graphic material of the projects, which places them, from the beginning, within the history of modern architecture.

\section{Measurement and analysis \\ Project of bottling plant "Coca-Cola" in Quart de Poblet, Valencia (1958)}

Mauro Lleó signed the initial project of bottling plant in 1958, the only one in collaboration with Luis Albert, and successive extensions until March 1971, the date of the fifth and last expansion designed for the company.

The architects, following the modern precepts, made a separation between the road and pedestrian traffic, premise in which would coincide the three projects that are presented. The pedestrian traffic placed it in the main façade, after a garden of sinuous forms that combined different materials together with small plates of water and streams that rested on a green tapestry that unified everything, with the will to want to recreate the field in an environment Industrial and with a great amount of traffic of which they looked for, certainly, to protect themselves. The remaining accesses to the plant, such as those for truck services, were solved by the perpendicular and parallel streets to the avenue so that they did not cross the pedestrian access and the main road access with the service roadside. In addition, there was also an interior street that separated the main building from the workshop, leaving enough space for truck parking.

The project spaces were in accordance with the functional program that was given to the architects with the assignmentand contemplated areas of production, sales, administration, general offices and management, and visits 
or propaganda. Thus, the bottling plant was initially formed by two buildings, one of them the main one that would meet the described areas and a second building of workshops that was not shown in the project floor plans. (Fig. 1, Fig. 2)

The main building, still indebted to the Gutiérrez-Soto models in terms of finishing materials such as brick and glass mosaic, played in its composition with simple volumes of one or two floors that successfully matched the program that contained each one of them. The first volume was an inverted L-shaped body of a single, closed plant, with an interior height of three meters and with an access porch that occupied all its main front to the avenue with a depth of four meters. In its interior, the program was organized in different

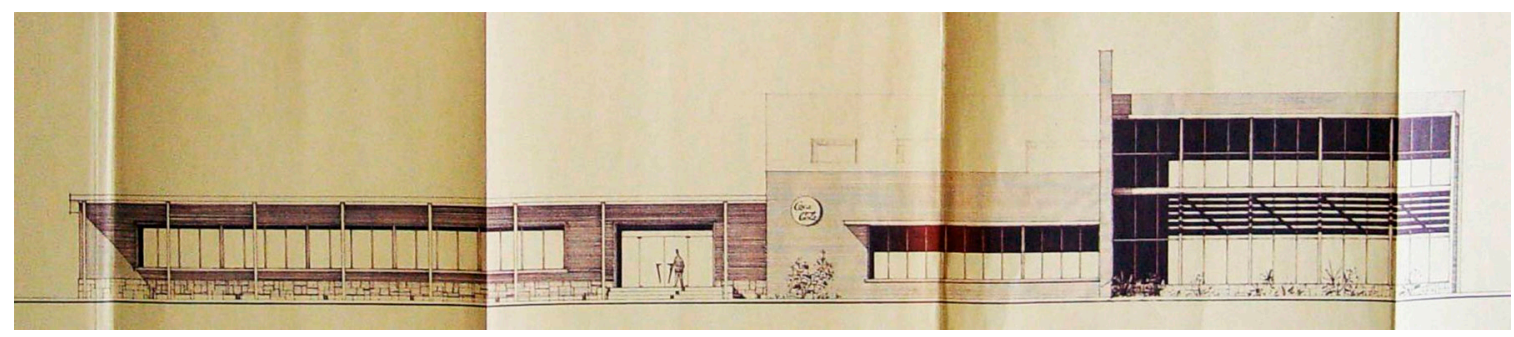

Figure 1. (South façade of the main building according to the Coca-Cola bottling plant project. June 1958)

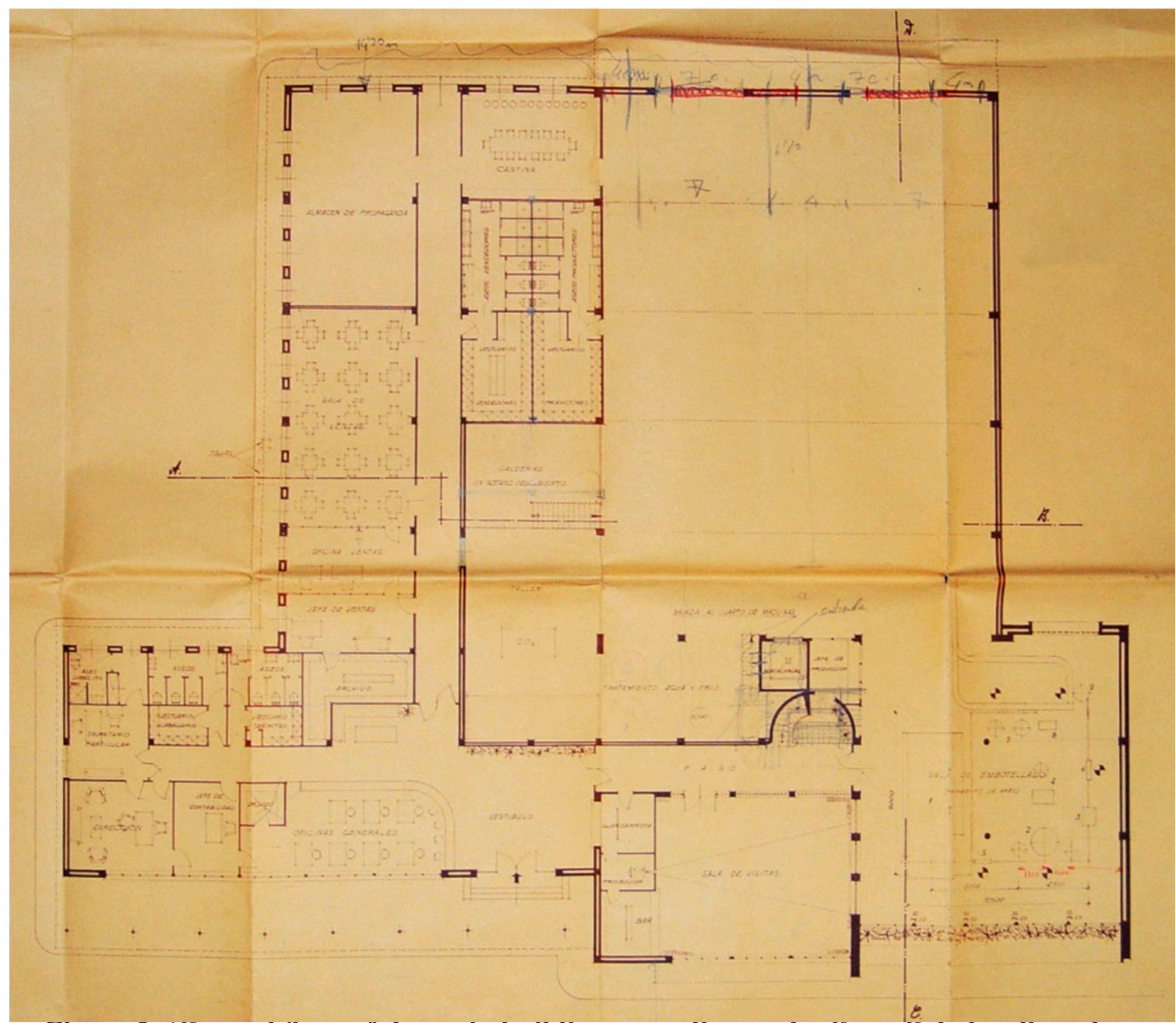

Figure 2. (Ground floor of the main building according to the Coca-Cola bottling plant project. June 1958) 
areas that included a large reception hall and offices, service area, changing rooms, canteen, publicity store and sales chiefs, accounting and management.

Secondly, a two-storey parallelepiped containing the production area and visits and which in turn was messed with the warehouse. In the main façade this volume was divided in two equal parts by a wall that stood out in both plant and height, giving importance and presence to the space where Coca-Cola was produced. It was an element that acted as a claim where, in addition, was placed the logo of the mark to make it visible for vehicles that accessed the capital from the Madrid highway. Inside, the visitor room, the bottling room, the office of the production manager and the water and cold treatment area on the ground floor and first floor, the storage of the various products needed to manufacture the Coca "Cola, they completed the program.

Finally, the warehouse, in a parallelepipedic form of twenty-three meters of light, formed by five gullies of six and twenty-five meters solved with a cover in the form of a sawtooth. This left openings oriented north for the natural lighting of the warehouse that were solved with a fixed metalwork closed with armed glass, a resource that would become the hallmark of all the architect's industrial projects.

The construction presented different types of openings and solutions depending on the orientation and the representativeness of the façade. Thus, on the southern main façade the building opened to the visitor and the access road to the city showing its interior with large glazing that invited to enter. Given the orientation of this façade, the bottling room protected itself from the sunshine with a "fixed horizontal aluminum shutter", as the project's memory said, another of the resources that would characterize Mauro Lleó's buildings, both teachers and industrialists. In addition, this façade, set back two meters in relation to the line marked by the living room, solved this space with a garden that did not prevent the vision of what happened inside but protected from excessive approchement.

The whole structure of the building was solved with reinforced concrete except the cover in sawtooth of the warehouse and the pillars of the access portico and hollows of facade, the first resolved with profiles of steel drawn in cold of five inches of internal diameter and the latter through two UPN 140.

\section{The metal processing plant FLEX in Quart de Poblet, Valencia (1961)}

On a site near the bottling plant, the new building for the metal processing plant was built. This construction occupied part of the same foreseeing a growing development of the industry with possible future extensions by the north and the west, leaving a garden space of protection against the avenue as it happened in the bottling plant "Coca-Cola".

The factory set designed by Mauro Lleó, consists of three completely differentiated volumes. The main building, five stories high and rectangular in shape, is the highest volume of the whole. Constructed with a reinforced concrete structure with pillars and hanging beams, the architect began to show in this the structural reticule as a compositional resource in façade that took center stage when being located in the exterior plane of that volume. In its southern main orientation, the space between the interior façade and the grid of pillars, not accessible from the upper floors, was occupied by horizontal slabs of reinforced concrete fabricated "in situ". Was solved in each floor with a face wall, of different height depending on the level, and glazing closing the rest of the height to the upper floor. (Fig. 3, Fig. 4)

This building was designed for delicate works of low load organized vertically from top to bottom, the ground floor being intended for exhibition, offices, archives and address, with a direct access to the area of sale on its façade to the Castilla Avenue. The upper floors, from first to fifth, were diaphanous, illuminated and ventilated by three of their facades (east, west and main south), all of which were intended for the manufacture of carcasses. It is striking the organization of the work in vertical remembering the spinners English of nineteenth century.

The rest of the enclosures of this volume, 


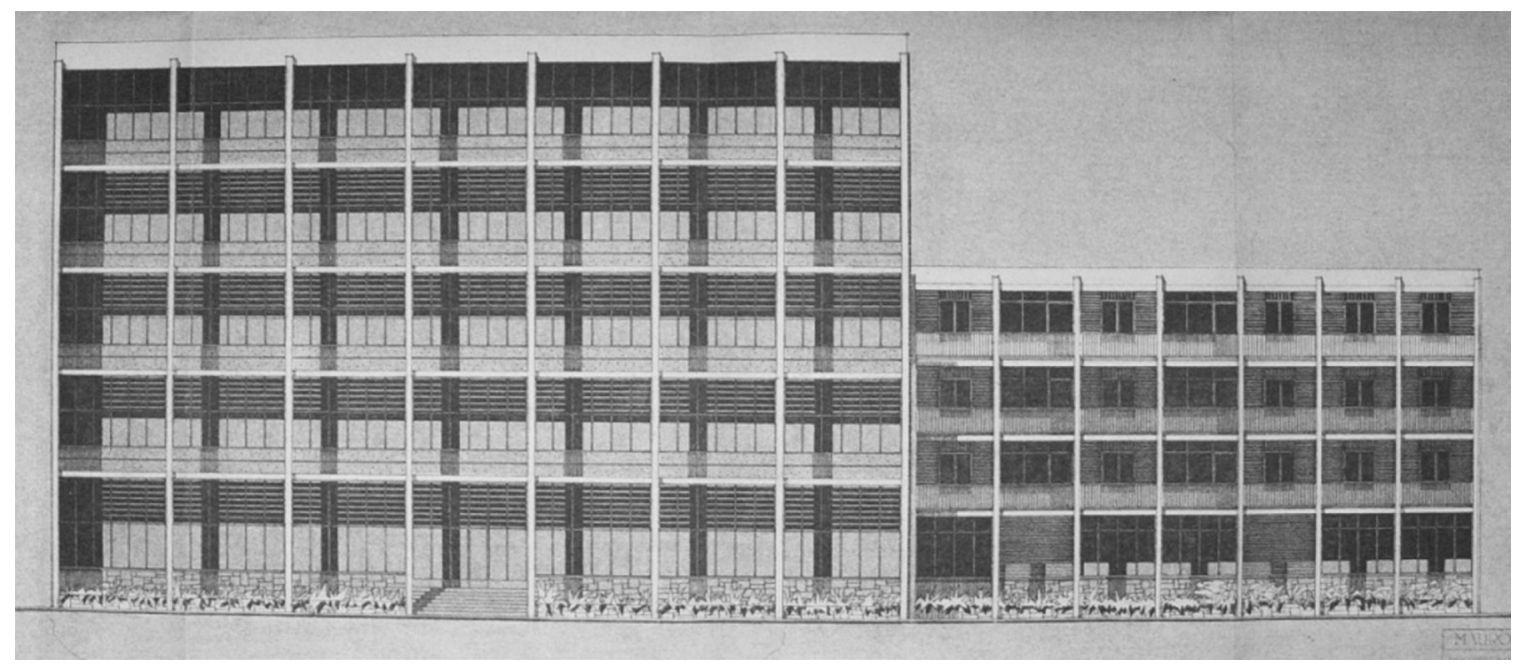

Figure 3. (Plan $n^{0} 5$, modified, south façade. Metal processing plant FLEX. May 1961)

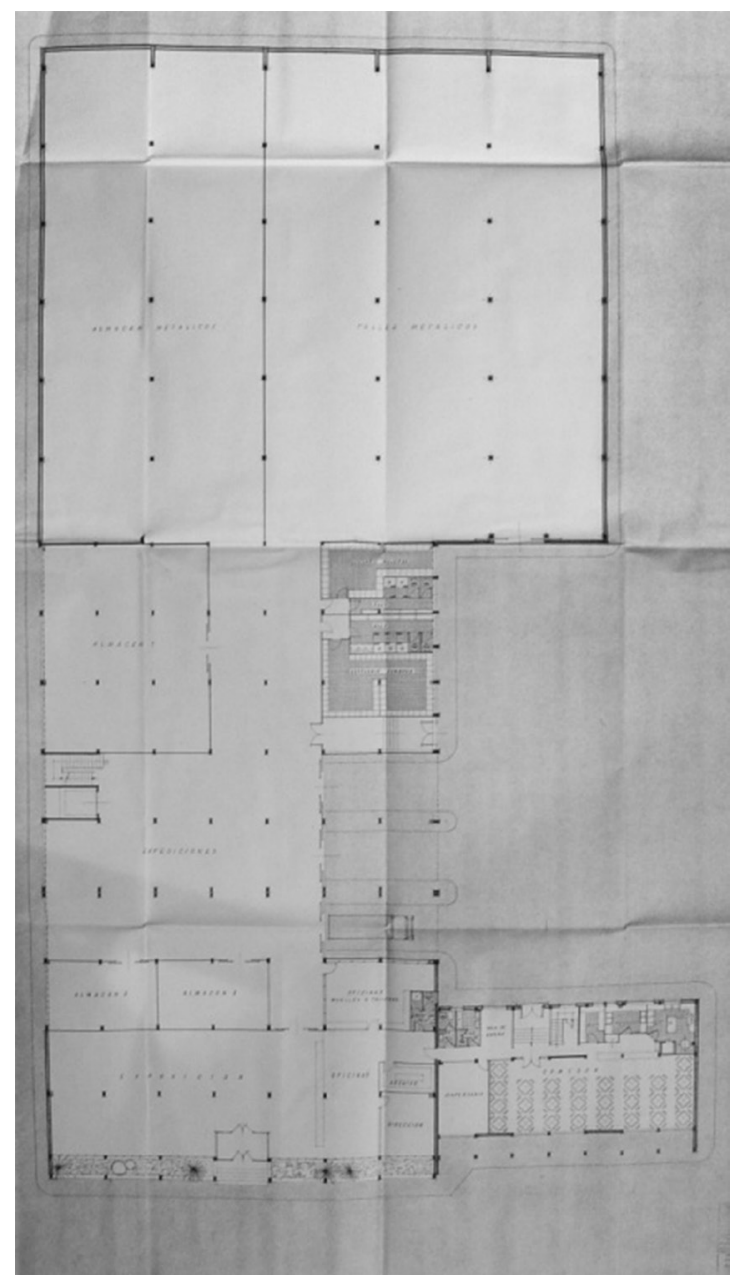

Figure 4. (Plan $n^{0}$ 2, ground floor. Metal processing plant FLEX. May 1961) and still needing sun protection in some orientations like the west, were solved in line of façade, again showing the reinforced concrete grid of the structure of the building, with façade brick panels and windows in its high part closing the holes left by the structure. The next volume was a single-storey warehouse for forging and mechanization workshops and metal warehouses. This building was covered with a metal structure in the form of saw teeth that generated openings oriented to the north for the natural illumination of the warehouse, reason why its facade closure was totally blind. Again the lighting resort north on the deck featuring the building.

Finally, the whole has a third block, a fourstorey parallelepiped for services and houses, which solves its southern facade with the same resource as the main building, keeping the structural grid of reinforced concrete in the foreground and retracting the enclosure with Respect to this. However, there is a clear desire of the architect to give maximum prominence to the main industrial building so that it is ahead of the housing, generating a shadow that visually increases the distance between them. The main structure of the factory is reinforced concrete for two fundamental reasons, for the ease of an immediate execution and for its greater resistance to fire. Given the dimensions of the whole, three expansion joints should be located, which can be clearly seen both on the floor and on the façade. Two of them corresponded to the separation between the different blocks: between the main building and the warehouse, and between the main 
building and the building of services and houses. The third, however, was located in the main building, approximately at its midpoint. It is worth mentioning the reticular structure of the main building composed of perpendicular porticos to the southern façade, with a distance of four to sixty meters, while the light between pillars was five and fifty meters. This separation was according to the engineers of the industry, "the ideal for the kind of work to be done". The slabs were projected from ribbed slabs with reinforced concrete vaults vibrated as lost formwork that, as the memory commented, could be replaced by a similar prefabricated system as Pratton. Therefore, although still concrete, the lattice is confirmed as a compositional resource that brings the architect closer to the Miesian constructive solutions with the desire, in addition, to substitute as far as possible the constructive systems of mounting slabs "in situ" by other prefabricated units that would have improved lead times.

Building project for the S.E.A.T. (Spanish Society of Tourism Cars, S.A.) in Valencia (1965)

Mauro Lleó was commissioned to design and direct the construction of the building for the Seat branch in Valencia in 1963. The project, which was finally drafted two years later, would be the step towards standardized construction and prefabrication, although still with misgivings, in the solution of its façades with curtain walls, brise-soleil and metal canopies.

Compositionally, the building responded to the six-meter module, which the company marked as a premise for all its projects, distributing around five buildings (A, B, C, D and $\mathrm{E}$ ) around an inner courtyard that resolved each one of them. Height and dimension, a part of the program given to the architect. Among these, volumetrically highlighted the workshop building again by the solution of its sawtooth roof, and the vehicle exhibition building, which was not finally built, a geodesic sphere of steel and glass, "a very unique element of attraction, a glass polyhedron surrounded by a garden and only united by very light elements of a single plant ", as explained by the architect in a letter to the Mayor of Valencia in response to the refusal to grant a license of works for the branch in 1965. A drawing of the architect of the whole of the building, would serve for his presentation before the property advancing the image of what would be the project once executed. (Fig. 5, Fig. 6)

Building A consists of two floors. The first or low was destined in its northwest part to access of workers, control, wardrobe, medicine cabinets and the warehouse, that bordered with the building $\mathrm{B}$, that was destined to mechanic shop. In the second plant was located the workshop of sheet, the warehouse of sheet and the dining rooms of workers. Building A had a width of five modules, that is, thirty-two meters.

Building B consists of five floors. The first (ground floor) was for the main access of the cars to the branch, lines of acceptance, service station, diagnosis and offices of the Technical Assistance Service, while on the second floor (first floor), was located the coupon line and the revised car depot. On the third (second floor), the tuning lines and the tank of cars were ready for delivery, and finally the fourth and fifth plants were exclusively destined to deposit new cars. All of these plants were connected to each other by ramps, a staircase and an elevator. This building also had a basement floor for conditioning services, generator set and elevator equipment, which did not occupy more than three modules of the area adjacent to building A.

Building $\mathrm{C}$, on a single floor, was used to store spare parts with their corresponding offices. The D, for its part, was composed of two plants. The first (or low) was for access to office staff, employee locker rooms, sales offices and car deposit for immediate delivery and the second for offices. Finally, building E was intended for exhibition and was attached directly to building $\mathrm{B}$ and $\mathrm{D}$.

The façades in this project have great importance since they are the signs of identity, the image of modernity that the brand intends to project. In addition, they are designed and executed perfectly according to their orientation and belonging to a particular block 


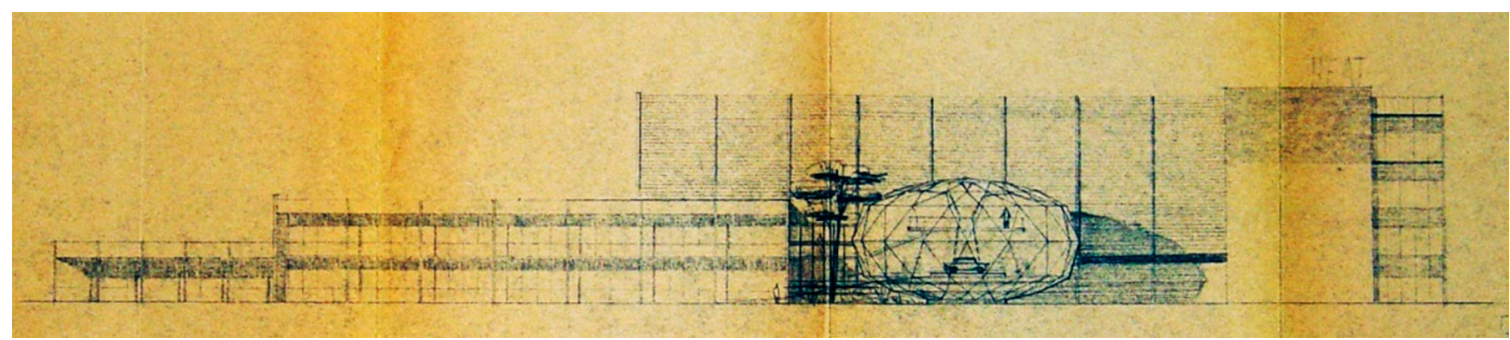

Figure 5. (Main elevation of the proposed Seat branch in Valencia, March 1964)

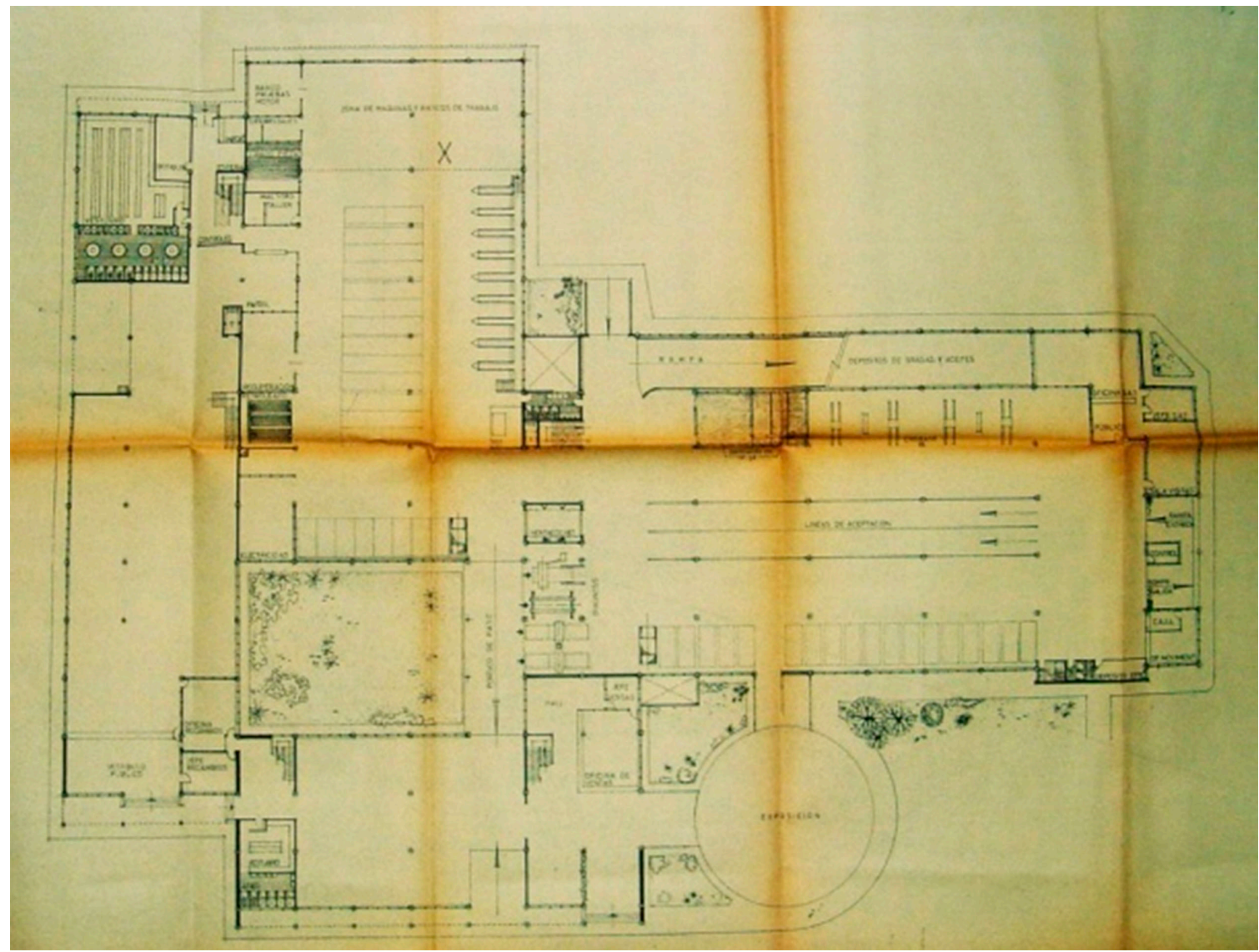

Figure 6. (Ground floor of the building project for the Seat branch of Valencia in May 1965)

of the whole, using resources already tested by the architect in their project of bottling plant Coca-Cola or La Pureza School, near the Seat building, as they are for example the horizontal canopies on the south facade of building D.

Like the plants, all the façades were worked following the Seat module of six to forty meters, thus having a total correspondence with the structure of the building, which made it a completely harmonic ensemble. This module, or the division of the same in equal parts, was visible in the carpenters, in the curtain walls and also in the frames of the brise-soleil of the façade of building B. It was therefore a module that accompanied the façade in its entirety and was well marked in the planes of elevation and detail.

The building had to be built in the shortest possible time, which led, among other things, to the use of metal structure and the maximum use of prefabricated elements on the façade, apart from those referring to the type of local construction, which is why large pieces of brick appeared or lined with white artificial stone. Among the prefabricated materials that Mauro Lleó used were panels of Glasal, Ytong and carpentry and brise-soleil of CASA, which reflected in its project plans. 
The Glasal was used as part of a sandwich panel of the company PANASA that formed by white Glasal, insulating and blue Glasal on its outer face. With a total thickness of thirtyeight millimeters and cloths of one with twenty by one with fifty meters approximately, this one was placed in part of the enclosures of the warehouse and store of spare parts.

CASA's Brise-Soleil consisted of aluminum grid panels that combined effective control of sunlight with a wide flexibility in design, appearance and finish. Its special design fins, mounted in grooves inclined on profiles, had the advantage of controlling solar energy effectively. The profiles were extruded in high quality aluminum alloy as well as the sheets for the manufacture of the fins and the clamping elements were of aluminum and stainless steel to prevent their corrosion. Although it was allowed to be assembled in three ways, panels supported, cantilevered or suspended, the suspended panels of an auxiliary structure directly supported in the structure of the building were mounted in the branch.

CASA also designed the carpentry of the curtain wall of the north façade of the car deposit building that acquired with this the character of automobile showcase. So, at night, when the building was turning on its lights, it showed the new vehicles inside, on several floors, acting as a complaint to the prospective buyer. The model used to solve this facade was the S-45 Arcadia series. The cloths between the carpentry were solved with fixed glass and, in the case of having openings, these were sliding.

\section{Conclusion}

From 1953 onwards a recovery in industrial activity began in Spain, although the change of orientation in the growth model of the Spanish economy had its starting point definitive in the Economic Stabilization Plan of 1959 that stopped inflation, devalued the peseta and was followed by measures liberalizing imports.

In the international context, the moment was also favorable for an intermediate-lowlevel country of development to open up to the outside world, since the main European economies, as well as the United States and
Japan, lived the longest and Intense economic growth in history and could exert a significant drag on the Spanish economy through trade and direct investment.

And that is how the east-west axis linking the city of Valencia with Madrid grew, urbanistically and economically, becoming a powerful axis in terms of communications thanks to its strategic situation but also in a large advertising platform where the most important in the industrial and commercial sector of the moment. These include the Coca-Cola bottling plant (1958), the Flex metal transform factory (1961) and the Seat subsidiary (1965), whose buildings, all of them by the same architect, Mauro Lleó Serret (1914-2001). They became pioneers of modernity in the city.

\section{References}

Alonso de Armiño Pérez, L., Jordá Such, C. and Vidal Vidal, V. M. (2002) Fondo Documental del s. XX, Comunitat Valenciana (Colegio Oficial de Arquitectos de la Comunitat Valenciana, Consejería de Obras Públicas, Urbanismo y Transporte, Instituto Valenciano de la Edificación, Valencia)

AA.VV. (2010) Equipamientos I. Lugares públicos y nuevos programas, 19251965. Registro DO.CO.MO.MO. Ibérico (Fundación Caja de Arquitectos, Fundación DO.CO.MO.MO. Ibérico, Barcelona)

AA.VV. Equipamientos II. Ocio, deporte, comercio, transporte y turismo. Registro DO.CO.MO.MO. Ibérico, 1925-1965. (Fundación Caja de Arquitectos, Fundación DO.CO.MO.MO. Ibérico, Barcelona)

Bravo, R. and Canovas, A. (1991) "La arquitectura de la Comunitat Valenciana", Arquitectos 1991, 120.

Calduch Cervera, J. (2009) "El declive de la arquitectura moderna: deterioro, obsolescencia, ruina", Palapa IV, núm. II.

Costa, X., Landrove, S.(dir). (1991) Arquitectura del Movimiento Moderno. Registro DO.CO.MO.MO. Ibérico, 19251965. (Fundación Mies van der Rohe y DO.CO.MO.MO. Ibérico, Barcelona)

Gaja Díaz, F. and Boira Maiques J. V. (1994) 
"Planeamiento y realidad urbana en la ciudad de Valencia (1939-1989)". Cuadernos de Geografía 55, 63-89.

García Braña, C., Landrove, S., Tostoes, A. (2005) La arquitectura de la industria, 19251965. Registro DO.CO.MO.MO. Ibérico. (Fundación DO.CO.MO.MO. Ibérico, Barcelona)

Jordá Such, C. (1997) 20x20. Siglo XX, veinte obras de arquitectura moderna (Colegio Oficial de Arquitectos de la Comunitat Valenciana, Conselleria d'Obres Públiques, Urbanisme i Transports, Valencia)

Jordá Such, C. (2007) "Docente y moderna. Crónica del panorama valenciano actual". Arquitectura viva, 103.

Lleó Serret, M.(1971) “El artey el planeamiento urbano". Archivo de Arte Valenciano 1971. 